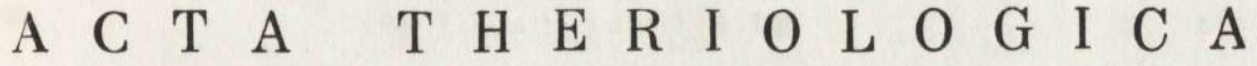 VOL. XIII, 18: 313-327.

John B. GENTRY, Frank B. GOLLEY

and Michael H. S M I T H

\section{An Evaluation of the Proposed International Biological Program Census Method ior Estimating Small Mammal Populations*)}

\author{
[With 3 Figs. \& 5 tables]
}

\begin{abstract}
Polish workers have proposed a method of estimating small rodent populations based on removal trapping. Using a linear regression method, they obtained reliable population estimates with five days of prebaiting followed by five days of removal trapping. The aim of our study was to compare the results obtained, using the same method at the Atomic Energy Commission's Savannah River Plant in the Southeastern United States, with the results of the Polish investigators. Our study area consisted of 5.8 ha over which a grid of 256 trap stations was arranged with two-snap traps at each station. Since by the fifth day of trapping, the number of daily captures had not declined, the trapping period was extended to cover 27 days. An increase in daily captures was observed between the 13th and 15th day in three of the four most common species. These fluctuations in capture rates were believed to be due to behavioral changes in the population. The results from this study indicated that at least nine days of trapping were necessary to obtain reliable estimates for the population as a whole. Even so, reliable estimates could not be calculated for two of the four most common species after 27 days of removal trapping.
\end{abstract}

\section{INTRODUCTION}

Several investigators have studied methods of censusing small mammal populations (H y ne, 1949; Calhoun, 1964; Grodziński, Pucek \& Ryszkowski, 1966; Ryszkowski, Andrzejewski \& Petrusewicz, 1966; and others). These studies have shown that the results of a census program may depend upon the weather, species present, intra- and interspecific interactions, population density,

*) This study was carried out under contract AT(38-1)-310 between the University of Georgia and the United States Atomic Energy Commission. 
type of trap, presence or absence of prebaiting, and so forth. The simple effects and interactions of all of these factors make it difficult to compare the results of different studies. Uniform census methods are needed to avoid these problems.

Since different areas of the world are involved in the International Biological Program (IBP), any proposed small mammal census technique must produce results that are comparable between widely separated geographic regions. Polish investigators, experienced in testing census methods (Andrzejewski, Bujalska, Ryszkowski \& Ustyniuk, 1966; Grodziński, et al., 1966; Ryszkow$\mathrm{sk} \mathrm{i}$, et al., 1966), have proposed using a grid of kill traps $(240 \mathrm{~m}$ on a side with 16 rows and lines and $15 \times 15 \mathrm{~m}$ spacing) which are prebaited for five days and then set for five days. The regression method of $\mathrm{H}$ a y ne (1949) is used to estimate rodent numbers. G rodziń s k i et al. (1966), reported that population estimates made by using the proposed trapping method normally fall within $10 \%$ of the total number of animals captured. The aim of the present study is to test the feasibility of the proposed International Biological Program census method for estimating small mammal populations on the Atomic Energy Commission's Savannah River Plant in South Carolina in the United States.

\section{METHODS}

A 5.8 ha grid, consisting of 256 stations spaced $15 \mathrm{~m}$ apart, was laid out in a mature cove hardwood forest. Two Victor mouse snap-traps were placed at each station. The traps were prebaited with peanut butter for five days. On the sixth day the traps were set and checked, and were rebaited and reset as necessary each day thereafter. Location of capture, sex, reproductive condition and weight of each animal were recorded. In order to test the effectiveness of the five days of removal trapping, the period of trapping was extended to 27 days from 26 September to 22 October, 1967.

After five days of trapping, it was suspected that some of the small mammals might be active in trees and were thus escaping capture by the snap-traps on the ground. To check this, two lines of drop-door live traps were set through the middle of the study area. These trap lines consisted of 16 traps per line with one trap at each station at about eye-level height on a small wooden platform nailed to a tree.

\section{HABITAT DESCRIPTION}

The study area could be divided into three different habitat types. On the drier slopes upland hardwoods covered 2.6 ha. This type was dominated by oak (Quercus spp.) and hickory (Carya spp.). Lowland hardwood-swamp forest, located in the flat, damp stream bottom, covered 2.7 ha and was dominated by sweetgum (Liquidambar styraciflua), black gum (Nyssa sylvatica), yellow poplar (Liriodendron tulipifera) and lowland oaks (Quercus spp.). Many of the shrubs and trees in the 
lowland hardwood swamp were covered with vines, which were mostly wild grap (Vitis spp.) and greenbriar (Smilax spp.). A small area of old-field habitat ( $0.5 \mathrm{ha}$ ), dominated by broomsedge (Andropogon spp.) and scattered second-growth pines (Pinus spp.), extended into the eastern border of the study area.

\section{RESULTS}

A total of 124 small mammals were captured during the 27-day trapping period. Sixty $(48 \%)$ of the total were short-tailed shrews, Blarina brevicauda (S a y, 1823), 27 (21\%) were cotton mice, Peromyscus gossypinus (L e C on te, 1853), 21 (17\%) were southeastern shrews, Sorex longirostris $\mathrm{B}$ a c h m a n, 1837, $12(10 \%)$ were golden mice, Ochrotomys nuttalli (A udubon \& Bachman, 1841), $3(2 \%)$ were eastern woodrats, Neotoma floridana ( $\mathrm{O} \mathrm{rd}, 1818)$ and 1 (1\%) was an eastern mole, Scalopus aquaticus (L in n a u s, 1758).

Five of the $12 \mathrm{O}$. nuttalli were captured in the traps located in trees. The three $N$. floridana captures were incidental since the traps were too small to accurately census this species. In fact, the three woodrats were found nearby the trap after being stunned by the trap. The capture of the mole was also incidental.

\section{Rate of Removal of Rodents}

Taking the total number of each species captured during the study as $100 \%$, the cumulated percentages of individuals caught on successive days were calculated. By the fifth day of trapping, $63 \%$ of the B. brevicauda, $48 \%$ of the $P$. gossypinus and $42 \%$ of the total number of animals had been captured. S. longirostris first appeared in the traps on the sixth day and $O$. nuttalli on the eighth day. By the ninth day, $87 \%$ of the B. brevicauda, $59 \%$ of the P. gossypinus, $67 \%$ of the $S$. longirostris, $25 \%$ of the $O$. nuttalli and $70 \%$ of the total number of animals had been trapped. Ninety-eight per cent of the B. brevicauda, $93 \%$ of the P. gossypinus, $90 \%$ of the S. longirostris, $83 \%$ of the $O$. nuttalli and $94 \%$ of total number of animals had been captured by the 18 th day.

There were three periods during the study in which successive declines were observed in the rate of removal of small mammals. Linear regression equations were fit to the data for days $1-9,10-18$ and 19-27 (Fig. 1). A regression line was also plotted for days $1-5$ in order to make possible a direct comparison with the same period from the results of Grodzinski, et al. (1966). The associated $r$ values indicated that the linear regressions representing the four trapping periods were significant at the 0.01 level; $r=0.98$ ( $1-5$ days), 0.99 ( $1-9$ days), 0.99 ( $10-18$ days) and 0.97 (19-27 days). 


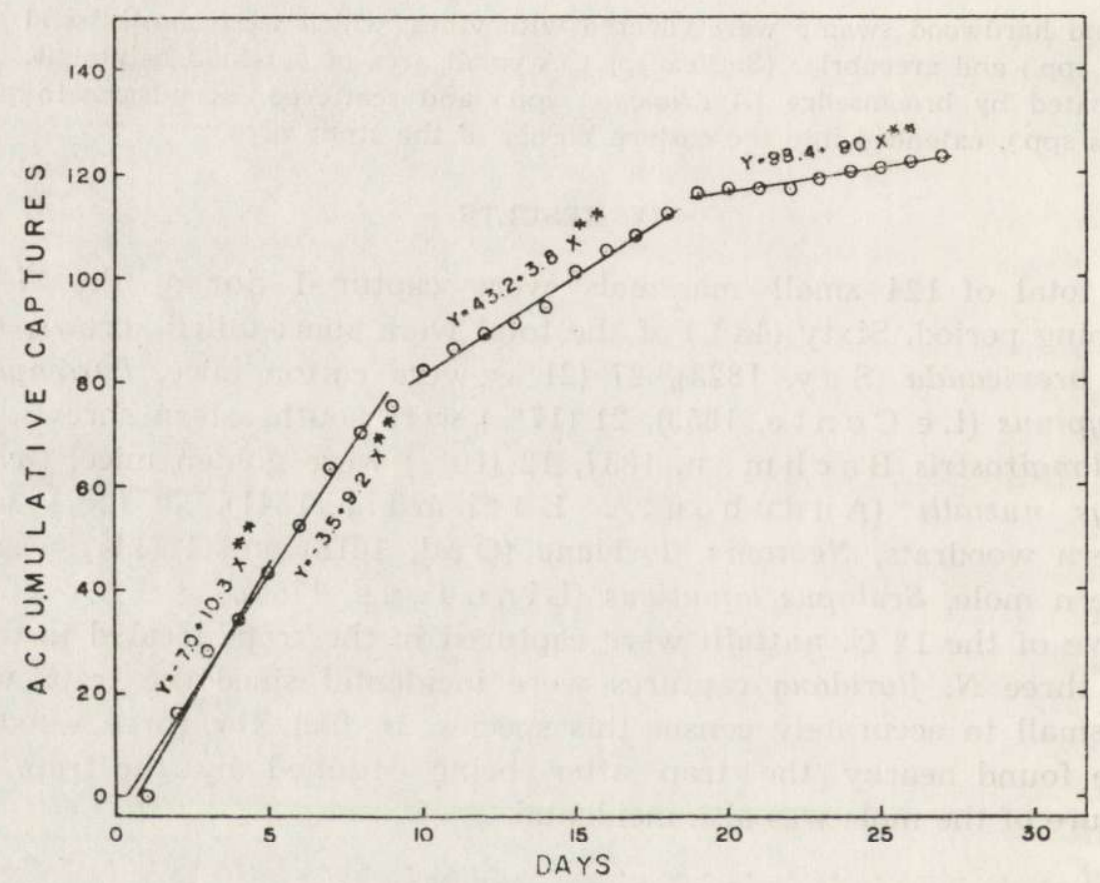

Fig. 1. Linear regressions for successive capture periods within the 27-day removal period $(* * r$ values significant at the .01 level).

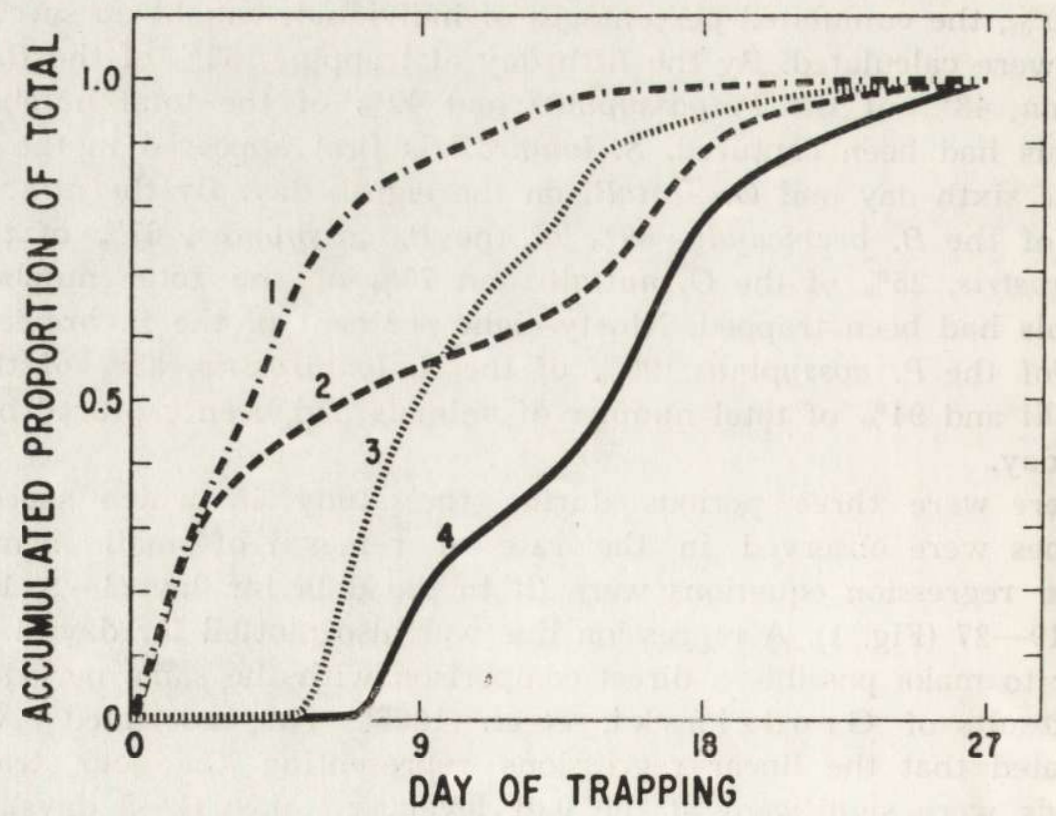

Fig. 2. Removal rates of four different species of small mammals (1) Blarina brevicauda; (2) Peromyscus gossypinus; (3) Sorex longirostris; (4) Ochrotomys nuttalli. 
The initial rate of capture eventually declined with time followed by a secondary increase (Fig. 2). These secondary increases only occurred in three species ( $P$. gossypinus, S. longirostris and $O$. nuttalli).

\section{Estimation of Small Rodent Numbers}

The linear regression method ( $\mathrm{H}$ a y $\mathrm{n}$ e, 1949) was used to estimate the numbers of small mammals (Table 1). The resulting equation,

Table 1.

Summary of the statistical analyses used in estimating the numbers $(N)$ of each species and all species combined according to the method of $\mathrm{H}$ a y $\mathrm{n}$ e (1949). The resulting equations take the form of $\mathrm{Y}=a+b \mathrm{X}$, where the ordinate is the number of captures per day, a the intercept, $b$ the slope and $X$ the cumulative number of animals previously captured.

\begin{tabular}{|c|c|c|c|c|c|}
\hline \multirow{2}{*}{ Species } & \multirow{2}{*}{$\begin{array}{c}\text { Statistical } \\
\text { Parameters }\end{array}$} & \multicolumn{4}{|c|}{ Trapping Period (Days) } \\
\hline & & $1-5$ & $1-9$ & $1-18$ & $1-27$ \\
\hline Blarina brevicauda & $\begin{array}{l}a \\
b \\
r^{2} \\
N\end{array}$ & $\begin{array}{l}9.6 \\
-0.12 \\
0.539 \\
80.0\end{array}$ & $\begin{array}{l}10.4 \\
-0.15 \\
0.647^{* *} \\
69.3\end{array}$ & $\begin{array}{l}10.7 \\
-0.17 \\
0.803^{* *} \\
62.9\end{array}$ & $\begin{array}{l}10.8 \\
-0.18 \\
0.841^{* *} \\
60.0\end{array}$ \\
\hline Peromyscus gossypinus & $\begin{array}{l}a \\
b \\
r^{2} \\
N\end{array}$ & $\begin{array}{l}5.1 \\
-0.37 \\
0.691^{*} \\
13.8\end{array}$ & $\begin{array}{c}4.8 \\
-0.31 \\
0.670^{*} \\
15.5\end{array}$ & $\begin{array}{l}3.2 \\
-0.13 \\
0.246^{*} \\
24.6\end{array}$ & $\begin{array}{l}2.9 \\
-0.11 \\
0.365^{* *} \\
26.4\end{array}$ \\
\hline Sorex longirostris & $\begin{array}{l}a \\
b \\
r^{2} \\
N\end{array}$ & $\begin{array}{l}\bar{z} \\
\overline{-}\end{array}$ & $\begin{array}{l}0.80 \\
0.17 \\
0.102 \\
-4.7\end{array}$ & $\begin{array}{c}1.24 \\
-0.02 \\
0.190 \\
62.0\end{array}$ & $\begin{array}{c}1.32 \\
-0.05 \\
0.080 \\
26.2\end{array}$ \\
\hline Ochrotomys nuttalli & $\begin{array}{l}a \\
b \\
r^{2} \\
N\end{array}$ & $\begin{array}{l}\bar{z} \\
\overline{-}\end{array}$ & $\begin{array}{l}0.13 \\
0.19 \\
0.781^{*} \\
-0.7\end{array}$ & $\begin{array}{l}0.24 \\
0.12 \\
0.257 \\
-2.0\end{array}$ & $\begin{array}{l}0.44 \\
0.00 \\
0.000 \\
0.0\end{array}$ \\
\hline All species $* * *$ & $\begin{array}{l}a \\
b \\
r^{2} \\
N\end{array}$ & $\begin{array}{c}14.0 \\
-0.18 \\
0.660^{*} \\
82.7\end{array}$ & $\begin{array}{l}13.5 \\
-0.10 \\
0.580^{*} \\
135.0\end{array}$ & $\begin{array}{l}13.0 \\
-0.09 \\
0.720^{* *} \\
144.4\end{array}$ & $\begin{array}{c}13.4 \\
-0.10 \\
0.829^{* *} \\
134.0\end{array}$ \\
\hline
\end{tabular}

* Associated $r$ values significant at the .05 level

** Associated $r$ values significant at the .01 level

*** Also includes Neotoma floridana and Scalopus aquaticus

$Y=a+b X$, where $Y$ equals the number of mice caught each day and $X$ equals the accumulative number of captures, can be used to calculate the population size $(N)$ by setting $Y=O$ and solving the equation for $X$. Linear regression lines for the four dominant species and all species combined are shown in Figure 3. Since $S$. longirostris and $O$. nuttalli 
did not appear in the traps until after the fifth day, there were no regression lines for these two species for days $1-5$.

The correlation coefficient $(r)$ for the reliability of the fit of the regression line to the data was statistically significant for all trapping periods for $B$. brevicauda except days $1-5$ and for all trapping periods for P. gossypinus. Estimates of B. brevicauda declined with each successive trapping period, while this trend was the opposite for P. gossypinus.
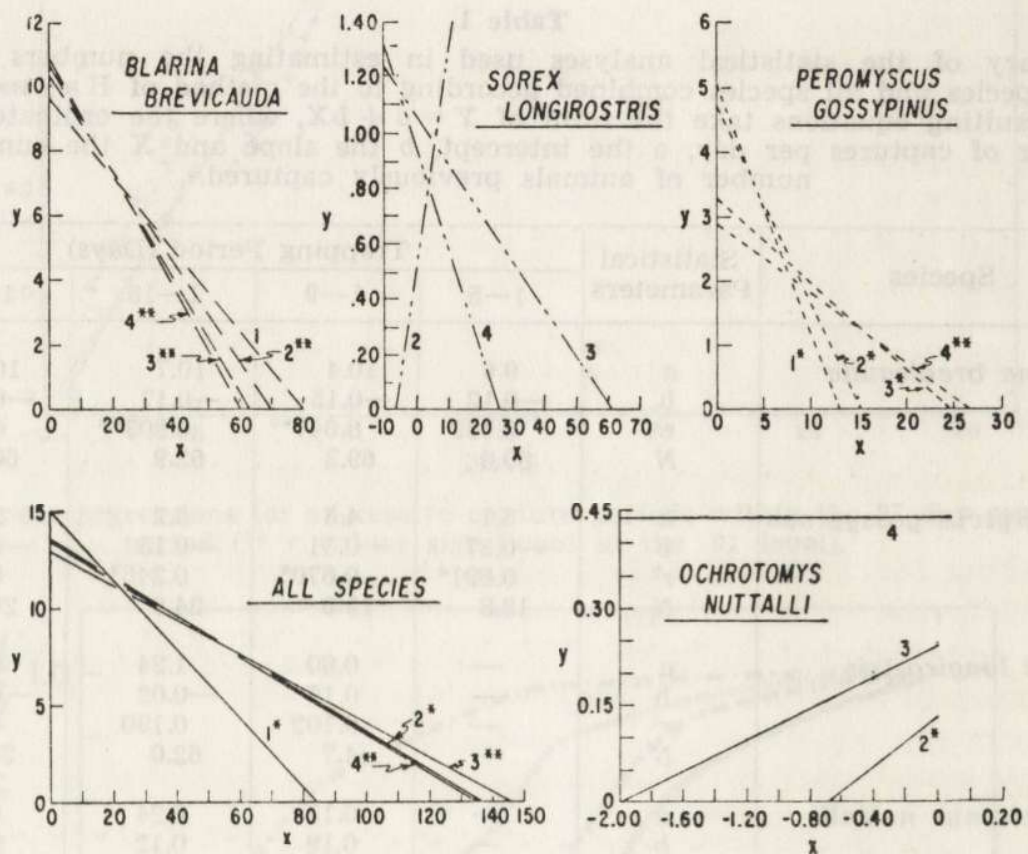

Fig. 3. Linear regressions used to obtain population estimates for four different species of small mammals and all species combined. Daily captures are plotted on the $Y$ axis and the cumulative number previously caught on the $X$ axis. See Table 1 for values of the regression formula. The numbered lines represent successive capture periods $(1$ : days $1-5 ; 2$ : days $1-9 ; 3$ : days $1-18 ; 4$ : days $1-27)$. Significant values: * $r$ significant at .05 level; **' $r$ significant at .01 level.

The correlation coefficients for $S$. longirostris and $O$. nuttalli were not significant with the exception of the period of day $1-9$ for $O$. nuttalli. In addition, the slope of the regression lines calculated for days $1-9$ for $S$. longirostris and days $1-9$ and $1-18$ for $O$. nuttalli was positive. The regression line for days $1-27$ for 0 . nuttalli had a slope of zero. Thus, estimates could not be derived for these periods for these two species, since the line must intersect the $X$ axis and have a negative slope. 
The correlation coefficient was significant for all trapping periods when all species were combined (Fig. 3). The estimate increased dramatically from days $1-5$ to days $1-9$. Estimates for the last three periods were less variable.

Population numbers estimated by the regression method $\left(N_{1}\right)$ were compared with the number of animals actually captured $\left(N_{2}\right)$ using index $A=\left(N_{2}-N_{1}\right) \times 100 \div N_{2}$ (Grodziński, et al., 1966). The absolute value of the difference between these two estimates is expressed as the percentage of the total number of animals caught during a given period (Table 3). Index A should be small and the population estimates should not vary dramatically with time if we are to have confidence in the proposed method.

Index $A$ for $B$. brevicauda varied from 110.5 per cent at 5 days to zero per cent at 27 days. The index for $P$. gossypinus varied between $2.0 \%$ and $6.1 \%$ over the four capture periods. If the population estimates had not shifted drastically over time (Table 3 ), then the low values and uniformity of index $A$ would have indicated that the technique worked well for $P$. gossypinus. The population estimates for $B$. brevicauda also shifted with time. The indices for $S$. longirostris during days $1-9$ and for $O$. nuttalli during the last three successive trapping periods could not be calculated because of negative estimates. When the data for all species are combined, index $A$ ranged from $64.6 \%$ at 9 days to $8.1 \%$ at 27 days. Grodziński, et al. (1966) reported mean values of index $A$ at $10.9 \%(2.9-50.0)$ for three dominating species of rodents and $10.3 \%(2.5-30.5)$ for combined species of rodents. Their data were obtained from eight different trapping areas and based on regression estimates calculated for periods ranging from $3-6$ days.

With the exception of days $1-9,1-18$ and $1-27$ for $P$. gossypinus, all estimates calculated from regressions were greater than the number of animals removed. Grodzińs k i, et al., (1966) reported that the estimates calculated from the regressions were smaller than the number of animals removed.

\section{Sex Ratios and Reproduction}

Assuming a 50:50 sex ratio, significantly more $B$. brevicauda females (Table 2) were caught then males $\chi^{2}=26.66$; df $=1 ; P<.001$ ). Also, significantly more female $S$. longirostris were caught than males $\left.\chi^{2}=3.86 ; \mathrm{df}=1 ; P<.05\right)$. Captures of male and female $P$. gossypinus did not differ from the expected $\left.\chi^{2}=1.81 ; \mathrm{df}=1 ; P>.05\right)$. T e r$\mathrm{m}$ a n \& S a s s a man (1967) reported that in four of five $P$. gossypinus population studies, significantly more males than females were captured. 
Although more $B$. brevicauda females than males were caught, the males were removed initially at a greater rate. At the end of five days of trapping, $90 \%$ of the males had been removed as compared to $58 \%$ of the females (Table 3). Similarily, $59 \%$ of the $P$. gossypinus males

Table 2.

Number of each sex caught over a 27 -day period. The percentage of pregnant females was based on the number of adult specimens of each species.

\begin{tabular}{|l|c|c|c|}
\hline \multicolumn{1}{|c|}{ Species } & $\begin{array}{c}\text { Number } \\
\text { Males } \\
\text { Caught }\end{array}$ & $\begin{array}{c}\text { Number } \\
\text { Females } \\
\text { Caught }\end{array}$ & $\begin{array}{c}\text { Per Cent } \\
\text { Pregnant }\end{array}$ \\
\hline Blarina brevicauda & 10 & 50 & 6.0 \\
Peromyscus gossypinus & 17 & 10 & 50.0 \\
Sorex longirostris & 6 & 15 & 0.0 \\
Ochrotomys nuttalli & 5 & 7 & 50.0 \\
Neotoma floridana & 2 & 1 & 0.0 \\
Scalopus aquaticus & 1 & 0 & - \\
\hline
\end{tabular}

Table 3.

Rate of removal of small mammals by sex. Removal rates are expressed as the per cent of the total number of animals captured at the end of 27 days with the numbers captured for each sex in parentheses. Also listed are the total number caught (actual $N$ ) and the number estimated (estimated $N$ ) by the regression method. The numbers indicating index $A$ are expressed as a per cent (see text).

\begin{tabular}{|c|c|c|c|c|c|}
\hline \multirow{2}{*}{ Species } & \multirow{2}{*}{ Observation } & \multicolumn{4}{|c|}{ Trapping Period (Days) } \\
\hline & & $1-5$ & $1-9$ & $1-18$ & $1-27$ \\
\hline Blarina brevicauda & $\begin{array}{l}\text { males } \\
\text { females } \\
\text { actual } N \\
\text { estimated } N \\
\text { index } A\end{array}$ & $\begin{array}{c}90(9) \\
58(29) \\
38 \\
80 \\
110.5\end{array}$ & $\begin{array}{l}90(9) \\
86(43) \\
52 \\
69 \\
33.3\end{array}$ & $\begin{array}{c}100(10) \\
98(49) \\
59 \\
63 \\
6.6\end{array}$ & $\begin{array}{c}100(10) \\
100(50) \\
60 \\
60 \\
0.0\end{array}$ \\
\hline Peromyscus gossypinus & $\begin{array}{l}\text { males } \\
\text { females } \\
\text { actual } N \\
\text { estimated } N \\
\text { index } A\end{array}$ & $\begin{array}{l}59(10) \\
30(3) \\
13 \\
14 \\
6.1\end{array}$ & $\begin{array}{l}65(11) \\
50(5) \\
16 \\
15 \\
3.1\end{array}$ & $\begin{array}{l}94(16) \\
90(9) \\
25 \\
24 \\
2.0\end{array}$ & $\begin{array}{c}100(17) \\
100(10) \\
27 \\
26 \\
2.2\end{array}$ \\
\hline Sorex longirostris & $\begin{array}{l}\text { males } \\
\text { females } \\
\text { actual } N \\
\text { estimated } N \\
\text { index } A\end{array}$ & $\begin{array}{l}0(0) \\
0(0) \\
0 \\
- \\
-\end{array}$ & $\begin{array}{l}33(2) \\
53(8) \\
10 \\
- \\
-\end{array}$ & $\begin{array}{l}83(5) \\
93(14) \\
19 \\
62 \\
244.4\end{array}$ & $\begin{array}{l}100(6) \\
100(15) \\
21 \\
26 \\
24.8\end{array}$ \\
\hline Ochrotomys nuttalli & $\begin{array}{l}\text { males } \\
\text { females } \\
\text { actual } N \\
\text { estimated } N \\
\text { index } A\end{array}$ & $\begin{array}{l}0(0) \\
0(0) \\
0 \\
- \\
-\end{array}$ & $\begin{array}{l}20(1) \\
29(2) \\
3 \\
- \\
-\end{array}$ & $\begin{array}{l}80(4) \\
86(6) \\
10 \\
- \\
-\end{array}$ & $\begin{array}{c}100(5) \\
100(7) \\
12 \\
-\end{array}$ \\
\hline
\end{tabular}


were removed by the fifth day of trapping while $30 \%$ of the females were removed. On the other hand, there was a tendency for S. longirostris females to be removed initially at a greater rate than males (Table 3). At the end of nine days of trapping, $53 \%$ of the females had been removed while $33 \%$ of the males had been removed.

Table 4.

Chi-square analyses of the number of captures of each species and all species combined vs habitat type. The expected values are based on the assumption that each animal had an equal chance of capture regardless of sex or habitat and were adjusted according to the number of traps in each habitat.

\begin{tabular}{|c|c|c|c|c|}
\hline Species & Habitat & $\begin{array}{c}\text { Observed } \\
\text { Number } \\
\text { Caught }\end{array}$ & $\begin{array}{r}\text { Expected } \\
\text { Number } \\
\text { Captured }\end{array}$ & $\chi^{2}$ \\
\hline \multirow[t]{2}{*}{ Blarina brevicauda } & $\begin{array}{l}\text { Lowland Hardwood-Swamp } \\
\text { Upland Hardwood } \\
\text { Old Field }\end{array}$ & $\begin{array}{r}47 \\
13 \\
0\end{array}$ & $\begin{array}{r}30.5 \\
24.6 \\
4.9\end{array}$ & $\begin{array}{l}8.90 \\
5.48 \\
4.92\end{array}$ \\
\hline & Subtotal & 60 & 60.0 & $19.30^{* *}$ \\
\hline \multirow[t]{2}{*}{ Peromyscus gossypinus } & $\begin{array}{l}\text { Lowland Hardwood-Swamp } \\
\text { Upland Hardwood } \\
\text { Old Field }\end{array}$ & $\begin{array}{r}18 \\
9 \\
10\end{array}$ & $\begin{array}{r}13.7 \\
11.1 \\
2.2\end{array}$ & $\begin{array}{l}1.34 \\
0.39 \\
2.22\end{array}$ \\
\hline & Subtotal & 27 & 27.0 & 3.95 \\
\hline \multirow[t]{2}{*}{ Sorex longirostris } & $\begin{array}{l}\text { Lowland Hardwood-Swamp } \\
\text { Upland Hardwood } \\
\text { Old Field }\end{array}$ & $\begin{array}{r}19 \\
2 \\
0\end{array}$ & $\begin{array}{r}10.7 \\
8.6 \\
1.7\end{array}$ & $\begin{array}{l}6.52 \\
5.08 \\
1.72\end{array}$ \\
\hline & Subtotal & 21 & 21.0 & $13.32^{* *}$ \\
\hline \multirow[t]{2}{*}{ Ochrotomys nuttalli } & $\begin{array}{l}\text { Lowland Hardwood-Swamp } \\
\text { Upland Hardwood } \\
\text { Old Field }\end{array}$ & $\begin{array}{r}12 \\
0 \\
0\end{array}$ & $\begin{array}{l}6.1 \\
4.9 \\
1.0\end{array}$ & $\begin{array}{l}4.78 \\
3.97 \\
0.23\end{array}$ \\
\hline & Subtotal & 12 & 12.0 & $8.98^{*}$ \\
\hline \multirow[t]{2}{*}{ All species $* * *$} & $\begin{array}{l}\text { Lowland Hardwood-Swamp } \\
\text { Upland Hardwood } \\
\text { Old Field }\end{array}$ & $\begin{array}{r}99 \\
25 \\
0\end{array}$ & $\begin{array}{l}63.0 \\
50.9 \\
10.1\end{array}$ & $\begin{array}{l}20.61 \\
13.14 \\
10.14\end{array}$ \\
\hline & Subtotal & 124 & 124.0 & $43.89^{* * *}$ \\
\hline
\end{tabular}

* Significant at the .05 level

** Significant at the .001 level

*** Also includes Neotoma floridana and Scalopus aquaticus

The weights of $B$. brevicauda and $S$. longirostris showed little varation and fell within the range of published adult weights (Golley, 1966). However, based on weights and pelage color, it was determined that $52 \%$ of the $P$. gossypinus and $33 \%$ of the $O$. nuttalli were juveniles. 
The heavier individuals of $P$. gossypinus were removed first. The total number of $P$. gossypinus caught was divided into halves in the order of their capture. Significantly more smaller animals (juveniles) than expected occurred in the second half of the total number of $P$. gossypinus removed $\left(\chi^{2}=8.11 ; \mathrm{df}=1 ; P<.001\right)$, assuming that each animal, regardless of size, had an equal chance of capture during the period of removal. Sample size was insufficient to test for this trend in O. nuttalli.

\section{Habitat Utilization}

There were significant relationships between the number of animals of each species captured per trap and the habitat in which they were captured (Table 4). With the exception of $P$. gossypinus, significantly more animals were caught in the lowland hardwood-swamp habitat type than expected when compared with the number captured in the remaining two habitats. $P$. gossypinus captures were scattered over both the upland and lowland hardwood habitat types. $\mathrm{M} \mathrm{c} \mathrm{Carley}$ (1954) showed that in eastern Texas, where $P$. gossypinus is sympatric with $P$. leucopus, the distribution of $P$. gossypinus was restricted to lowland hardwood areas, which was not the case in this study.

A few isolated mature pine trees with a dense layer of pine litter occurred in the area. A comparison was made between the number of captures at stations with pine litter $(N=31)$ and those at stations without pine litter $(N=225)$. Fewer animals $(N=4)$ were captured at stations with pine litter than was expected $(N=15)$ assuming each animal had an equal chance of capture at each trap regardless of habitat $\left(\chi^{2}=31.47 ; \mathrm{df}=1 ; P<.001\right)$.

More $O$. nuttalli were taken in the traps placed in trees $(N=5)$ than was expected $(N=0.7)$, assuming each animal had an equal chance of capture at each trap $\left(\chi^{2}=21.6 ; \mathrm{df}=1 ; P<.001\right)$. The tree captures occurred on trees which were covered with vines. All O. nuttalli captures occured in the lowland hardwood-swamp habitat (Table 4). All of the other species were caught in traps set on the ground.

\section{Movements into the Study Area}

In order to determine if animals were moving into the study area in response to the removal of resident animals, the trap grid was divided into an external belt containing three rows of traps and into an inner square containing 10 rows of traps. The outer belt contained 156 and the inner square 100 trap stations. The average number of animals for 
the four most common species captured per trap station was calculated for each area at days $1-5,1-9,10-18$ and $19-27$ (Table 5). There were no significant differences in the average number of animals captured per trap station between the two areas for each species or for all species together. The expected values were calculated by assuming that the probability of capture per trap was the same in both areas.

Table 5.

Distribution of captures of small mammals during three successive removal periods. Comparisons were made between the number of captures in an external belt with 156 trap stations and the number of captures in the remaining center square with 100 trap stations.

\begin{tabular}{|l|c|c|c|c|}
\hline \multirow{2}{*}{ Species } & Trapping & \multicolumn{3}{|c|}{$\begin{array}{c}\text { Number of Individuals } \\
\text { Per Trap Station }\end{array}$} \\
\cline { 2 - 5 } & $\begin{array}{c}\text { Period } \\
\text { (Days) }\end{array}$ & $\begin{array}{c}\text { External } \\
\text { Belt }\end{array}$ & $\begin{array}{c}\text { Inner } \\
\text { Square }\end{array}$ & $\chi^{2 *}$ \\
\hline \multirow{3}{*}{ Blarina brevicauda } & $1-9$ & 0.20 & 0.21 & 0.0 \\
Peromyscus gossypinus & $10-18$ & 0.03 & 0.02 & 0.0 \\
& $19-27$ & 0.01 & 0.00 & 0.0 \\
Sorex longirostris & $1-9$ & 0.06 & 0.07 & 0.1 \\
& $10-18$ & 0.05 & 0.01 & 2.3 \\
Ochrotomys nuttalli & $19-27$ & 0.01 & 0.00 & 0.5 \\
& $1-9$ & 0.05 & 0.02 & 0.6 \\
Total & $10-18$ & 0.03 & 0.05 & 0.1 \\
& $19-27$ & 0.01 & 0.01 & 0.0 \\
& $1-9$ & 0.01 & 0.02 & 0.0 \\
& $10-18$ & 0.02 & 0.04 & 0.2 \\
& $19-27$ & 0.01 & 0.01 & 0.0 \\
& $1-9$ & 0.31 & 0.32 & 0.6 \\
& $10-18$ & 0.13 & 0.12 & 0.0 \\
& $19-27$ & 0.03 & 0.02 & 0.0 \\
\hline
\end{tabular}

* Chi-square values corrected for continuity (Ste el \& Torrie, 1960)

On the other hand, A ulak (1967), working with small mammal populations in the Białowieża National Park in Poland, found that significantly more rodents were captured in the external belt than in the inner square, indicating movement into the study area. At the same time, he reported that there was rarely a significant difference between the number of shrews captured in the two zones of the study area. Similar results were reported by Grodziński, et al. (1966) for rodent populations. However, the densities of the small mammal populations studied by Aulak (1967) and Grodziński, et al. (1966) were greater than the densities observed in the present study. 


\section{DISCUSSION}

Estimates of small mammal numbers arrived at by using the $\mathrm{H}$ a y ne (1949) regression method are reliable only if it is assumed that: (1) All individuals in the population had an equal chance of capture on each day, (2) immigration and emigration were minimal during the period of study, and (3) mortality and reproduction during the removal period did not cause variations in numbers. All of these assumptions are rarely met in nature.

It is obvious from this study that a five day trapping period was insufficient to adequately estimate the population, even with five prior days of prebaiting. Had trapping been discontinued after five days, the presence of two of the common species ( $S$. longirostris and $O$. nuttalli) would have gone undetected. Furthermore, only $42 \%$ of the total number of animals caught were removed by the fifth day.

Reliable estimates for $B$. brevicauda could be made after nine days and for $P$. gossypinus after 18 days. Reliable estimates could not be made for $S$. longirostris and $O$. nuttalli. At least nine days of trapping were required to obtain a reliable estimate for the overall population on the area.

In all cases, estimates were greater than, or in the case of P. gossypinus, equal to, the number of animals removed. Grodziński, et al. (1966) reported that, in seven cases out of eight, numbers estimated by the regression method were smaller than the total numbers of rodents removed. They suggested this was due to a non-uniform probability of capture or the appearance of new individuals during removal.

The difficulties experienced in estimating the populations at the Savannah River Plant appeared to be the result of differences in the probability of capture within and between species. The removal of certain individuals and species may have caused others to alter their behavior and thus react to the traps differently.

C a lhoun (1964) analyzed data from a series of 30-day removal trapping studies and suggested that populations of small mammals were composed of dominant and subordinate species and individuals. Dominant species are thought to have large home ranges, contact more traps and therefore are removed at a greater rate than the subordinates. As the dominants are removed the subordinates are able to expand their home ranges and increase their exposure to traps. The increase in captures of subordinate animals results in a secondary increase in capture rates between the 13th and 15th day of trapping (Fig. 2). C a lhou n's theory and the secondary increase in capture rates point out a possible weakness of the proposed IBP census method for estimating small mammal populations. 
C a 1 houn (1964), in studies involving Peromyscus, Blarina and Sorex, also found that Peromyscus was the dominant species in all cases. But, it was not uncommon to capture more of the subordinate than the dominant species. Our data can be interpreted in terms of $\mathrm{C}$ a l hou n's theory (1964). We found that two times as many $B$. brevicauda were removed in 27 days as $P$. gossypinus, although $B$. brevicauda appeared to be the dominant species.

One might argue that the observed increase in daily captures was the result of immigration into the area as resident animals were removed. However, it was shown that there was no significant movement into the area from the outside, assuming that immigrating individuals would be caught in greater numbers in the external belt of traps than in the inner square of traps. W i e g e r t \& M a y e $\mathrm{nsch}$ e in (1966) reported that even in enclosures, where immigration is not a factor, removal of cotton rats (Sigmodon hispidus) was influenced by behavioral changes in the population.

It has been shown that changes in weather conditions can effect the trappability of small mammals (Sidor owicz, 1960; Gentry, Golle y \& M c Ginnis, 1966). Light rain occurred during the first and twenty-third nights of trapping. However, in general, weather conditions remained relatively constant during the study and was probably a minor factor in influencing estimates. Reproduction was also probably a minor factor as indicated by the overall low number of pregnant females (Table 2).

To summarize, we found that five days of removal trapping preceeded by five days of prebaiting, did not result in reliable estimates based on data from 27 days of trapping. At least nine days of removal trapping were needed to produce reliable estimates for the population as a whole. It was not possible to arrive at estimates for two of the more common species ( $S$. longirostris and $O$. nuttalli). The proposed IBP census method for estimating small rodent populations when applied to small mammal populations in a hardwood forest habitat in the Southeastern United States, did not yield results comparable to those reported by Polish investigators.

\section{REFERENCES}

1. Andrzejewski R., Bujalska G., Ryszkowski L. \& Ustyniuk J., 1966: On a relation between the number of traps in a point of catch and trappability of small rodents. Acta theriol., 11: 343-349.

2. A ulak W., 1967: Estimation of small mammal density in three forest biotopes. Ekologia Polska - Seria A, 15, 39: 755-778.

3. Calhoun J. B., 1964: The social use of space [In: M a yer W. and Van Gelder R. »Physiological Mammalogy «] Vol. 1: 1-187. Academic Press, N. Y. 
4. Gentry J. B., Golle y F. B. \& M c Ginnis J. T., 1966: Effect of weather on the captures of small mammals. Amer. Midl. Naturalist, 75: 526-530.

5. Grodziński W., Pucek Z. \& Ryszkowski L., 1966: Estimation of rodent numbers by means of prebaiting and intensive removal. Acta theriol., 11: $297-314$.

6. Golle y F. B., 1966: South Carolina Mammals. The Charleston Museum, Charleston, South Carolina, $181 \mathrm{p}$.

7. Hay ne D. W., 1949: Two methods for estimating population from trapping records. J. Mamm., 30: 399-411.

8. M c Carley H., 1954: The ecological distribution of the Peromyscus leucopus species group in eastern Texas. Ecology, 35: 375-379.

9. Ryszkowski L., Andrzejewski R. \& Petrusewicz K., 1966: Comparison of estimates of numbers obtained by the methods of release of marked individuals and complete removal of rodents. Acta theriol., 11: 329341.

10. Sidorowicz J., 1960: Influence of the weather on capture of Micromammalia. I. Rodents (Rodentia). Acta theriol., 4: 139-158.

11. Steel R. G. D. \& Torrie J. H., 1960: Principles and procedures of statistics. McGraw-Hill Book Company, N. Y., 481 p.

12. Terman C. R. \& Sas S a man J. F., 1967: Sex ratio in deer mouse populations. J. Mamm., 48: 589-597.

13. Wiegert R. G. \& M a yenschein J. C., 1966: Distribution and trap response of a small wild population of cotton rats (Sigmodon $h$. hispidus). J. Mamm., 47: 118-120.

Received, April 29, 1968.

Savannah River Ecology Laboratory

SROO, Box A

Aiken, South Carolina, USA 29801

Department of Zoology and

Institute of Ecology

University of Georgia

Athens, Georgia, USA 30601

John B. GENTRY, Frank B. GOLLEY i Michael H. SMITH

\section{WERYFIKACJA METODY OCENY LICZEBNOSCI POPULACJI MAEYCH SSAKOW, ZAPROPONOWANEJ DLA CELOW MIĘDZYNARODOWEGO PROGRAMU BIOLOGICZNEGO}

\section{Streszczenie}

Celem badań było sprawdzenie metody oceny liczebności populacji malych ssaków, zaproponowanej dla celów IBP. Badania prowadzono na terenach Komisji Energii Atomowej, w Południowej Karolinie (USA). Badacze polscy, Grodziński, Pucek i Ryszkowski (1966), posługując się metodą regresji Hayne’a (1949) otrzymali realne określenie liczebności populacji, w wyniku 5 dniowego przynęcania i następującego potem 5 dniowego wyławiania gryzoni.

Terenem badań był las liściasty, w którym na powierzchni 5,8 ha ustawiono sieć pulapek zabijających, po dwie w każdym z 256 punktów. Ponieważ w ciągu 5 dni ilość ssaków łowionych dziennie nie spadla widocznie, przedłużono okres wyłowu do 27 dni (od 26 września do 22 października 1967 r.). Wyłowiono ogółem 124 małe ssaki, wśród których $60(48 \%)$ stanowiła Blarina brevicauda (S a y, 1823), 
$27(21 \%)$ - Peromyscus gossypinus (L e Conte, 1853), $21(17 \%)$ - Sorex longirostris (B a chmann, 1837), $12(10 \%)$ - Ochrotomys nuttali (A u dubon et B a chma n, 1841), $3(2 \%)$ - Neotoma floridiana (O r d, 1818) i $1(1 \%)-$ Scalopus aquaticus ( $\mathrm{L}$ i n n a e s, 1758).

Początkowo tempo wyłowu spadało, lecz potem następował wtórny jego wzrost (Ryc. 2). Ten wtórny wzrost tempa wyłowu miał miejsce tylko u trzech gatunków, $P$. gossypinus, $S$. longirostris i $O$. nuttali.

Wszystkie oceny, otrzymane metodą regresji były wyższe, (w przypadku $P$. gossypinus - równe), niż ilość złowionych zwierząt (Ryc. 3). Realna ocena liczebności $B$. brevicauda mogla być dokonana po 9 dniach a $P$. gossypinus po 18 dniach wyłowu. Nie można było oszacować liczebności $S$. longirostris i $O$. nuttali. Dla realnych ocen liczebności populacji konieczny jest zatem co najmniej dziewięciodniowy okres wyłowu.

Przyjmując teoretyczny stosunek plci 50:50 stwierdzono, że złowiło się istotnie więcej samic niż samców B. brevicauda i S. longirostris (Tabela 3). W przypadku $B$. brevicauda i $P$. gossypinus samce początkowo wyławiały się szybciej niż samice, przeciwnie u $S$. longirostris, samice w pierwszym okresie wykazywały tendencję do szybszego wyłowu. W pierwszej kolejności wyławiały się również cięższe osobniki $P$. gossypinus.

Zaproponowana dla celów IBP metoda oceny liczebności gryzoni, zastosowana do populacji małych ssaków w poludniowo-wschodniej części Stanów Zjednocznnych, nie daje wyników porównywalnych z rezultatami badaczy polskich. 